\title{
A Decade of Genetic Counseling in Frontotemporal Dementia Affected Families: Few Counseling Requests and much Familial Opposition to Testing
}

\author{
S. R. Riedijk • M. F. N. Niermeijer • D. Dooijes • \\ A. Tibben
}

Received: 2 October 2008 / Accepted: 29 January 2009/Published online: 10 April 2009

(C) The Author(s) 2009. This article is published with open access at Springerlink.com

\begin{abstract}
A decade of genetic counseling of frontotemporal dementia (FTD) affected families has generated two important observations. First, the uptake rate for presymptomatic testing for FTD is low in our department of Clinical Genetics at the Erasmus Medical Center in the Netherlands. Second, FTD at-risk counselees reported substantial familial opposition to genetic testing, which is distinct from the attitude in Huntington Disease affected families. We hypothesize that the low acceptance for FTD genetic counseling is consequential to the familial opposition and explain this within the theoretical framework of separation-individuation. Furthermore, we hypothesize that separation-individuation problems do not similarly influence the acceptance of HD genetic counseling, due to the educative role of the well-organised patient organization for HD in the Netherlands. We offer counseling recommendations that serve to facilitate the
\end{abstract}

S. R. Riedijk $(\bowtie) \cdot$ D. Dooijes

Department of Clinical Genetics, Erasmus Medical Centre,

Westzeedijk 112,

3016 AH Rotterdam, The Netherlands

e-mail: s.riedijk@erasmusmc.nl

S. R. Riedijk

Department of Medical Psychology and Psychotherapy,

Erasmus Medical Centre Rotterdam Section of Clinical Genetics,

Rotterdam, The Netherlands

M. F. N. Niermeijer

Department Anthropogenetics,

University Medical Centre Nijmegen-St. Radboud,

Nijmegen, The Netherlands

A. Tibben

Centre of Human and Clinical Genetics,

and Department Neurology, LUMC,

Leiden, Netherlands individuation of the counselee with respect to the FTD genetic test.

Keywords Frontotemporal dementia - Genetic counseling . Separation-individuation · Presymptomatic testing .

Family opposition

\section{Frontotemporal Dementia}

Frontotemporal dementia (FTD) is a severe neurodegenerative disorder with onset at middle-adult age. Patients present with decline in interpersonal conduct, emotional blunting and loss of insight, all preceding memory decline (Snowden et al. 2002). As FTD advances, patients develop progressive disturbance of executive functions, loss of initiative, mental flexibility and organization. Language becomes impaired, eventually resulting in aphasia. FTD is the second most common presenile dementia, with a prevalence of 10-15 per 100.000 individuals of 45-65 years (Mercy et al. 2008; Rosso et al. 2003; van Swieten and Heutink 2008). There are identical risks for male and female offspring of an affected parent in the familial forms, which are estimated at $30-50 \%$ of total FTD (Rosso et al. 2003; Seelaar et al. 2008).

Mutations are found in $30-40 \%$ of cases with a positive family history (Rosso et al. 2003; Van der Zee et al. 2008; Van Swieten et al. 2004). There are at least five genes associated with FTD and its subtypes, and even more when one considers the overlap with Alzheimer disease and motor neuron disease (Van der Zee et al. 2008). The microtubule associated protein tau gene (MAPT) was the first FTD gene identified in 1998 (Sleegers et al. 2008), followed by the progranulin gene $(G R N)$ in 2006. The $M A P T$ and GRN mutations are variably found in some 10- 
$20 \%$ of familial FTD series (Rademakers et al. 2007; Rademakers et al. 2008). The mean age of onset of FTD with a MAPT mutation is $52.4 \pm 5.9$ years (Van Swieten et al. 2004) and with a $G R N$ mutation it is $61.8 \pm 9.9$ years (Rademakers et al. 2008; Seelaar et al. 2008). For both diseases, the penetrance is high, that is, $90-95 \%$ of mutation carriers will become affected by 70 years. The clinical spectrum seen with identical mutations may vary from Alzheimer disease, Lewy Body disease, corticobasal syndrome, frontotemporal dementia, frontotemporal lobar dementia, FTD-ALS to primary progressive aphasia, etc.

When the disease-causing gene is identified in a family, presymptomatic genetic testing becomes available. With the discovery of FTD causing genes (see for a review: Van Swieten 2007) gradually more families will be able to opt for genetic testing of patients, at-risk relatives and prenatal testing. However, the number of families tested for the less frequently observed mutations is still limited, which implies insufficient knowledge on the clinical variability of these mutations.

\section{Genetic Counseling in the Netherlands}

In presymptomatic genetic testing, healthy relatives, usually siblings or children of identified FTD probands, are enabled to obtain testing for the mutation causing FTD in their family. Family-specific and mutation-specific data on variability in age at onset and progression of the behavioral problems of FTD will be given, emphasizing the remaining uncertainties for newly identified gene carriers. The genetic counseling approach for FTD is similar to that for Huntington's disease (HD) (Brouwer-DudokdeWit et al. 2002) and involves three steps: intake, blood withdrawal, and test result disclosure in two or three sessions depending on the extent of information and decision process prior to the first visit. The counselee is seen by a clinical geneticist and a psychosocial counselor at all visits.

At intake, the clinical geneticist informs the counselee about FTD, the specific FTD related problems in the family, and the possible implications of testing. The geneticist aims to facilitate the counselee's decision-making about the choice for the test and its implications for his or her future. Special attention is given to social support in- or outside the family and to possible problems of obtaining employment and life- or other insurance when an FTD carrier status is found. Referral to specific information services is offered. At test disclosure the geneticist facilitates counselee expression of initial emotional reactions to the news and offers follow-up to support the counselee in coping with his or her new status, either as disease free or as a mutation carrier. The goal is adequate integration of the counselee's new status in daily living.
Psychosocial counselors, at intake, explore in-depth the motivation to seek testing, in order to raise awareness of the counselee's expectations with respect to testing. Counselees are encouraged to think about what a favorable or an unfavorable test result would mean to them personally, in order to make a head start in psychological processing of any test outcome. How does the counselee expect to feel upon hearing that she or he is or is not a carrier of the gene? What would change? How will either outcome affect the bonds within the family? How will the counselee maintain quality of life awaiting a future of FTD? Preparing for the outcome means anticipating a rather dramatic change: from uncertainty and hope towards certainty, with either a future with increasing distress, or liberated from the disease but possibly burdened for some period by guilt feelings towards affected relatives. In addition, the geneticist provides technical information on the genetics of FTD, the phenotype and penetrance, whereas the psychosocial counselor explores in-depth the psychological make-up and motivation of the counselee and the family dynamics with regard to the hereditary disorder, and discusses how this counselee may best adapt to either test outcome. Furthermore, the psychosocial counselor provides follow-up, and if necessary, referral to psychotherapy.

\section{Clinical Experience with Genetic Counseling for FTD in Rotterdam}

Mutation analyses for presymptomatic testing for FTD in the Netherlands were only performed in our Rotterdam diagnostic laboratory until 2007. The diagnostic laboratory of the Free University in Amsterdam has performed a few analyses since 2007. Nearly all counselees were seen at the department of Clinical Genetics of the Erasmus Medical Centre in Rotterdam. We made several important observations about clinical genetic testing for FTD. First, the uptake rate seemed to be quite low. After the identification of pathogenic MAPT mutations in 1997, 80 members of three large families who were at $50 \%$ risk and $>18$ years of age, were informed of the discovery of the pathogenic genes and were offered genetic counseling (Heutink et al. 1997). We estimated that this information would also reach another 100 adults at $50 \%$ risk in these families, and possibly more relatives at lower risk. Only thirteen individuals from this potential group of 180 people that were at $50 \%$ risk of being carriers requested genetic counseling between 1999 and 2002. Since we cannot be certain that the additional 100 adults were actually reached, the acceptance of counseling ranges somewhere between 7 and $17 \%$. The 13 counselees were on average 34 years of age (Range: 19-54), and of these counselees, 6 pursued the test. Five of these testees stated that resolving unbearable 
uncertainty with regard to carrying the mutation was an important motive for testing.

Since then, despite the discovery of other pathogenic FTD genes (Bronner et al. 2007; Seelaar et al. 2008), a mere 13 additional individuals have been counseled for FTD in our center between 2003 and 2008. Furthermore, during this decade (1999-2008) we received only one request for prenatal diagnosis (PND) in 1999, and no requests for pre-implantation genetic diagnosis (PGD) for FTD. The low uptake for FTD presymptomatic testing is in great contrast with the $24 \%$ uptake rate for Huntington's disease (HD) in the Netherlands in 2000 (Maat-Kievit et al. 2000), but it is comparable to low uptake rates for HD in other countries (Tibben 2007).

In our clinical work we have made some characteristic observations about our FTD population that warrant special note. Two of us (SR and AT) have counseled all at-risk individuals who presented themselves in our department for FTD counseling since 1999. All of these counselees reported experiencing clear opposition to genetic testing from their family members. Healthy parents of counselees disapproved of testing and siblings attempted to dissuade them from testing; they were resentful about the counselees' wish to discuss the hereditary nature of FTD within the nuclear family. Some counselees indicated that they consciously used the genetic test to liberate themselves from their oppressive and restrictive family. For them, genetic testing for FTD would either enable an independent, disease free life, or anticipation of a future disease without the additional burden of problematic family dynamics.

\section{Possible Explanation for Few FTD Genetic Test Requests: the Importance of Separation-Individuation}

Family members play an important role in the decision whether or not to pursue genetic testing (Bowles Biesecker et al. 2000; McDaniel 2005). The low uptake for FTD genetic testing may result from a high prevalence of enmeshed family structures and its effects on separation-individuation processes. The concept of separation-individuation was originally formulated by Margaret Mahler and refers to an intra-psychic process that infants go through in early childhood in ending their symbiotic relationship with their mother (Mahler 1963). Separation refers to the realization of self versus not self, and individuation pertains to the process of determining who and what the self is.

A second separation-individuation phase begins in adolescence and is generally seen as a transition of major importance in the family life cycle (Daniels 1990). Therein, young adults gain their independence from their family of origin while continuing to have a function in the family. During this phase adolescents develop relationships with peers, or a partner that become equally important as the relationship with the parents (Grootevant and Cooper 1986). Generally, the second phase of separation-individuation is thought to start in adolescence, but it remains a lifetime task (White et al. 1983).

From this family systems perspective separationindividuation is seen as the interchange between individuality and connectedness between the individual and the nuclear family members. We consider the separation-individuation process to be of major importance in the clinical genetics setting. A counselee who is sufficiently individuated is able to distinguish his or her feelings and wishes from the feelings and wishes of the nuclear family. A desire to pursue genetic testing then, is a wish that has its origin in the counselee and the counselee is free to assume the responsibility for processing the information and emotions surrounding the test and to cope with the result. Self-determination is combined with respectful acceptance of and disengagement from the feelings and reactions of the nuclear family. The counselee is able to tolerate that other family members deal with the genetic risk in her or his own way.

When counselees have not adequately accomplished the separation-individuation task, relations with the nuclear family are either enmeshed or disrupted. In enmeshed families the counselees' motives for testing tend to be fused with the normative values of their family. These counselees may pursue testing because the nuclear family pushes them in that direction or, on the contrary, refrain from testing under familial pressure. In enmeshed families taboo and secrecy frequently surround the disease. Genetic testing in such families may be instrumental allowing counselees to "escape" from family enmeshment. An unfavorable test result might excuse them from caregiver obligations, whereas a favorable outcome might empower them to build a new life.

Based on our decade of experience, FTD families seem to be particularly enmeshed. Several processes threatening adequate separation-individuation in FTD families may promote such enmeshment. First, in dealing with illness families tend to become more cohesive to carry the burden together (Rolland 1987). Such cohesion implies that in the face of a common threat families tend to stick together to support each other. To a certain degree family members will benefit from this cohesion. However, as Olson's (2000) Circumplex Model of family functioning describes, when the cohesion becomes too strong individual family members have less space to cope in their unique way, and the family becomes enmeshed. Enmeshed families become normative and exert pressure on members who deviate from this norm. Such enmeshment interferes with adequate separation-individuation.

Second, Goldman and colleagues (2004) noted that families affected by FTD seem to be psychologically 
damaged. Psychological damage may occur as a consequence of having an FTD- affected parent; FTD patients have inhibition problems. Their behavior is therefore a product of their impulses, which may cause them to be aggressive, promiscuous, unpredictable, etc. They lack disease insight, which results in their denial that anything is wrong. In addition, they become emotionally blunted and are unable to care about others. Furthermore, their executive functions are damaged, and therefore their ability to organize and plan activities is impaired. Clearly, FTD patients are unable to provide a stable and safe environment for their children in practical and emotional terms (Fanos 1997).

One of the most damaging aspects of FTD for family members is that these symptoms occur early in the disease process. Depending on the age of the children who are faced with a parent with FTD, they will be more or less prone to psychological damage. Children in the preverbal phase are especially prone to develop an insecure attachment style as has been demonstrated in HD families (Van der Meer et al. 2006). For these children, their parent's behavior will be particularly threatening. Insecure attachment combined with traumatic experience will lead to dysfunction with respect to several developmental processes, including separation-individuation (van Gael 2002).

If the parent develops FTD when the child is in adolescence, the separation-individuation process is at-risk. For adequate separation-individuation it is important that adolescents are able to rely on a stable relationship with their parents. Adolescents need the space to find out who they are and who they are not, but they also need to feel sufficient connectedness with their parents so that in this "letting go" process they do not lose their foundation (Barber 1997; Blos 1967). Adolescents with an FTD-affected parent may feel isolated because they are too embarrassed about their parent's behavior to bring friends home, and they may be unable to share their grief with their peers because generally adolescents do not have to deal with losing a parent. Given this complex situation at home, it may be more difficult to allow peers to become equally important as the nuclear family members (Carter and McGoldrick 2005).

Finally, it may be hypothesized that preoccupation with the future disease threatens adequate separation-individuation. In families affected by genetic disease young people may be preoccupied with the apprehension they will develop the disease in the future. This might be considered as "anticipatory loss" and a way to gain control over the future threat (Rolland 2006). A few of the counselees who presented for the genetic test for FTD described how they had grown up feeling they would be next. They had refrained from investing in significant relationships with persons outside of the nuclear family because they did not want to burden a potential partner with having to care for them once they developed FTD.
In summary, the separation-individuation task for persons in FTD-affected families may thus be corrupted by at least three phenomena. These include: family enmeshment in response to a common threat, psychological damage due to growing up with an FTD-affected parent, and preoccupation with the possibility of becoming symptomatic for FTD in the future.

\section{A Case Example of Impaired Separation-Individuation}

A woman in her twenties, Eva (pseudonym) presents herself for genetic counseling for FTD in our center. She is very ambivalent about the test. On the one hand she finds herself unable to deal with the uncertainty about her own genetic status. Eva closely monitors her behavior and cognitive functions, searching for any symptoms of FTD, which would confirm her greatest fears. She has refrained from investing in a "real relationship" because she would not want to burden a potential partner with her possible FTD. She believes that in order to know which turn her future will take, she needs to learn whether or not she will develop FTD. On the other hand, Eva worries that if she pursues testing, she is upsetting and betraying her healthy parent, her mother. Her mother has taken care of her FTD-affected father for many years and she is terrified of losing her daughter to FTD as well. Because of her fears she is unable to support Eva's pursuit of genetic testing. On the contrary, the mother wants Eva to support her by refraining from testing. Eva is afraid of damaging her relationship with her mother because she realizes that if she has FTD, she will need her mother to take care of her in the future.

Eva lost her father to FTD in early adulthood, implying that her father had FTD during her adolescence. During this period she was ashamed of her father's behavior and found it difficult to understand and accept that his emotional bluntness was due to the disease and not a rejection of her as a person. Because her mother had a hard time caring for her father and managing the household, she assisted her mother with many tasks. Eva felt quite lonely because her friends were mostly going out and dating whereas she was continuously worrying about and feeling responsible for the situation at home. She felt so different from her peers that she was unable to invest in friendships. When her father was institutionalized she stayed with her mother because she did not want to abandon her.

When finally her father died of FTD, Eva allowed herself to fully consider that she too was at-risk of developing this disease, and her attention shifted from her parents to herself. Based on her physical resemblance to her father she started to believe that there was a real chance that she would be the next person to develop FTD. Now that her father had died, Eva suddenly had to start building her own life. But FTD was looming behind every important decision 
she had to make. For five years she has found herself unable to make decisions and build a life of her own. This is why Eva has presented for genetic counseling. However, her mother's disapproval is greatly upsetting her. Eva believes that she will only be able to start living if she hears that she is not carrying the mutation, and that a negative test result would also greatly relieve her mother.

In HD the strong impact of a devastating dementia on familial relationships was amply demonstrated (Duisterhof and Tibben 2000; Duisterhof et al. 2002; Vamos et al. 2007). Members of HD affected families present more often with insecure attachment styles than the general population as a result of growing up with an affected parent (Van der Meer et al. 2006). Insecure attachment is a risk factor for adult psychopathology (Mickelson et al. 1997) The uptake rate for HD genetic counseling in the Netherlands is relatively high, and it has been noted that a self-selected group of resourceful and psychologically "healthy" individuals presents for genetic counseling (Decruyenaere et al. 2003; Tibben 2007). Therefore our impression of HD counselees may be biased, making comparisons to FTD counselees difficult. Still, among the small number of FTD counselees we have observed, familial opposition to testing has been particularly overt whereas we are no longer gathering similar impressions from HD counselees.

The first generation of testees for HD did report experiencing similar familial opposition to testing (Martindale 1987). However, HD became a paradigm for genetic testing and a very active patient organization emerged. The amount of attention in the medical, clinical and research settings and in the media have paved the way for at-risk family members to seek genetic counseling. In particular, the HD patient organization is helpful to HD at-risk family members. The HD patient organization works closely with families and medical professionals, providing information and guidance regarding long term care and genetic counseling needs, based on data from longitudinal studies. The organization serves an educative function in that it offers guidance as to how families might deal with genetic testing. Although we do not believe that a patient organization such as the one for HD in the Netherlands will guide family members through the entire separation-individuation process, we do think it may provide some support for that process. Even a highly enmeshed, damaged family that might at first not welcome genetic testing, might learn from the patient organization that individual members should be allowed to make their own choices with respect to genetic testing. In the Netherlands, such a patient organization is lacking for FTD. Given the absence of an educative patient organization, assisting counselees with individuation regarding genetic test wishes is a key task for the psychosocial counselor in the clinical genetics department.

\section{Counseling Recommendations}

In FTD genetic counseling we recommend that the counselor address the degree of separation-individuation of the counselee and her or his wish for genetic testing. Questions that may be helpful in assessing the degree of individuation regarding a test wish are: Has the counselee confided in any family member that she or he wishes to pursue genetic testing? Are the counselee's parents involved? How did siblings react? Has the counselee experienced support from the nuclear family? Is there openness or secrecy with regard to FTD in the nuclear family? How did the counselee reach the decision to come for genetic counseling? The answers to such questions will reveal the extent to which the counselee's wish for genetic testing has evolved in a sufficiently individuated manner. These questions will raise both the counselor's and the counselee's awareness of the context in which the wish for testing was shaped. If a wish for testing seems mostly reactive to family dynamics then this may be discussed as such. The counseling subsequently needs to address what consequences the genetic test may precipitate other than freeing oneself of the nuclear family, and whether the counselee is willing to accept these consequences as well.

Inherent to the wish to escape family enmeshment is the observation that mobilizing social support from the family may be particularly difficult for these individuals. Occasionally the psychosocial counselor may be the counselee's sole source of support, and if that is the case, then more than the standard three sessions should be offered.

Genetic counseling is not psychotherapy. Hence, we do not expect that geneticists will guide counselees completely through the process of adequate separation-individuation. However, addressing these issues might increase their awareness of the need for an independent decision with regard to testing. Subsequently, adverse effects of deciding in favor of the test and of either test outcome may be minimized. If needed, referral for additional psychotherapy may be offered.

Our impressions are based on a small number of testing cases and their families. Given the low uptake rate it is difficult to gather empirical data on this particular population. We have chosen to share our clinical impressions, and we invite others to provide their experience with genetic counseling and testing in FTD families. Through this discussion we aim to contribute to enhanced genetic counseling, testing and enriched psychological support of individuals at-risk for FTD and their families.

In summary, in our department of Clinical Genetics in Rotterdam, a mere 26 individuals at-risk for FTD have presented for genetic counseling over the last decade. We have observed that these counselees experienced pronounced familial opposition to genetic testing. We hypothesize that the low amount of requests for FTD genetic 
counseling is due to inadequate separation-individuation of the members of FTD affected families. In FTD families three processes may impair separation-individuation; 1) family cohesion that becomes too strong in the face of a threatening illness, leading to enmeshment, 2) growing up with an FTD-affected parent may lead to inadequate separation-individuation, and 3) preoccupation with the future disease may cause at-risk individuals to refrain from separating from the nuclear family. Furthermore, we hypothesize that separation-individuation problems do not similarly influence the acceptance of HD genetic counseling, due to the educative role of the well-organized patient organization for HD in the Netherlands. Geneticists should thus pay attention to the degree of separation-individuation evident in counselees' testing wishes. Geneticists should also be aware that they may represent a major source of support for FTD counselees, and tailor their approaches, accordingly.

Acknowledgements This paper was supported by the Dutch Research Council (NWO: 940-38-005).

Open Access This article is distributed under the terms of the Creative Commons Attribution Noncommercial License (https:// doi.org/creativecommons.org/licenses/by-nc/2.0/), which permits any noncommercial use, distribution, and reproduction in any medium, provided the original author(s) and source are credited.

\section{References}

Barber, B. K. (1997). Adolescent socialization in context: the role of connection, regulation, and autonomy in the family. Journal of Adolescent Research, 12, 5-11. doi:10.1177/0743554897121002.

Blos, P. (1967). The second individuation process of adolescence. In R. S. Eissler, A. Freud, H. Hartmann, \& M. Kris (Eds.), The psychoanalytic study of the child (vol. Vol. 22, (pp. 162-186)). New York: International Universities Press.

Bowles Biesecker, B., Ishibe, N., Hadley, D. W., Giambarresi, T. R., Kase, R. G., Lerman, C., et al. (2000). Psychosocial factors predicting BRCA1/BRCA2 testing decisions in members of hereditary breast and ovarian cancer families. American Journal of Medical Genetics, 93, 257-263. doi:10.1002/1096-8628 (20000814)93:4<257::AID-AJMG1>3.0.CO;2-8.

Bronner, I. F., Rizzu, P., Seelaar, H., Van Mil, S. E., Anar, B., Azmani, A., et al. (2007). Progranulin mutations in Dutch familial frontotemporal lobar degeneration. European Journal of Human Genetics, 15, 369-374. doi:10.1038/sj.ejhg.5201772.

Brouwer-DudokdeWit, A. C., Savenije, A., Zoeteweij, M. W., MaatKievit, A., \& Tibben, A. (2002). A hereditary disorder in the family and the family life cycle: Huntington disease as a paradigm. Family Process, 41(4), 677-692. doi:10.1111/j.15455300.2002.00677.x.

Carter, B., \& McGoldrick, M. (2005). The expanded family life cycle, individual, family and social perspectives (3rd ed.). Boston: Allyn and Bacon.

Daniels, J. A. (1990). Adolescent separation-individuation and family transitions. Adolescence, 25, 105-116.

Decruyenaere, M., Evers-Kiebooms, G., Cloostermans, T., Boogaerts, A., Demyttenaere, K., Dom, R., et al. (2003). Psychological distress in the 5-year period after predictive testing for Huntington's disease. European Journal of Human Genetics, 11, 30-38. doi:10.1038/sj.ejhg.5200913.

Duisterhof, M., \& Tibben, A. (2000). Childhood experiences with a parent with a hereditary late onset disease and the impact on wellbeing: a new direction in research. Journal of Medical Genetics, 37(suppl II), A9.

Duisterhof, M., Trijsburg, R. W., Duivenvoorden, H. J., \& Tibben, A. (2002). Are experiences with HD related to the attachment representation in adults at $50 \%$ risk for HD? An empirical exploration. European Journal of Human Genetics, 10(suppl I), 315.

Fanos, J. H. (1997). Developmental tasks of childhood and adolescence: implications for genetic testing. American Journal of Medical Genetics, 71(1), 22-28. doi:10.1002/(SICI)1096-8628 (19970711)71:1<22::AID-AJMG4>3.0.CO;2-S.

Goldman, J. S., MPhil, C. G. C., Farmer, J. M., Van Deerlin, V. M., Wilhelmsen, K. C., Miller, B. L., et al. (2004). Frontotemporal dementia: Genetics and counseling dilemmas. The Neurologist, 10, 227-234. doi:10.1097/01.nrl.0000138735.48533.26.

Grootevant, H. D., \& Cooper, C. R. (1986). Individuation in family relationships. A perspective on individual differences in the development of identity and role-taking skill in adolescence. Human Development, 29, 82-100.

Heutink, P., Stevens, M., Rizzu, P., Bakker, E., Kros, J. M., Tibben, A., et al. (1997). Hereditary frontotemporal dementia is linked to chromosome 17q21-q22: a genetic and clinicopathological study of three Dutch families. Annals of Neurology, 41(2), 150-159. doi:10.1002/ana.410410205.

Maat-Kievit, A., Vegter-van der Vlis, M., Zoeteweij, M., Losekoot, M., Van Haeringen, A., \& Roos, R. (2000). Paradox of a better test for Huntington's disease. Journal of Neurology, Neurosurgery, and Psychiatry, 69, 579-583. doi:10.1136/jnnp.69.5.579.

Mahler, M. S. (1963). Thoughts about development and individuation. The Psychoanalytic Study of the Child, 18, 307-324.

Martindale, B. (1987). Huntington's chorea: some psychodynamics seen in those at risk and in the responses of the helping professions. The British Journal of Psychiatry, 150, 319-323. doi:10.1192/bjp.150.3.319.

McDaniel, S. H. (2005). The psychotherapy of genetics. Family Process, 44, 25-44. doi:10.1111/j.1545-5300.2005.00040.x.

Mercy, L., Hodges, J. R., Dawson, K., Barker, R. A., \& Brayne, C. (2008). Incidence of early-onset dementias in Cambridgeshire, United Kingdom. Neurology, 71, 1496-1499. doi:10.1212/01. wnl.0000334277.16896.fa.

Mickelson, K. D., Kessler, R. C., \& Shaver, P. (1997). Adult Attachment in a nationally representative sample. Journal of Personality and Social Psychology, 73, 1092-1106. doi:10.1037/0022-3514.73.5.1092.

Olson, D. H. (2000). Circumplex model of marital and family systems. Journal of Family Therapy, 22, 144-167. doi:10.1111/ 1467-6427.00144.

Rademakers, R., Baker, M., Gass, J., Adamson, J., Huey, E. D., Momeni, P., et al. (2007). Phenotypic variability associated with progranulin haploinsufficiency in patients with the common $1477 \mathrm{C}$ ? [Arg493X] mutation: an international initiative. The Lancet Neurology, 6, 857-868. doi:10.1016/S1474-4422(07)70221-1.

Rademakers, R., Eriksen, J. L., Baker, M., Robinson, T., Ahmed, Z., Lincoln, S. J., et al. (2008). Common variation in the miR-659 binding-site of GRN is a major risk factor for TDP43-positive frontotemporal dementia. Human Molecular Genetics, 17, 36313642. doi: $10.1093 / \mathrm{hmg} / \mathrm{ddn} 257$.

Rolland, J. (2006). Living with anticipatory loss in the new era of genetics: a life cycle perspective. In C. WWN (Ed.), Individuals, families, and the New Era of Genetics: Biopsychosocial Perspectives (pp. 139-172). New York: W.WE.Norton \& Co.

Rolland, J. S. (1987). Chronic illness and the life cycle: a conceptual framework. Family Process, 26, 203-221. doi:10.1111/j.15455300.1987.00203.x. 
Rosso, S. M., Donker Kaat, L., Baks, T., Joosse, M., de Koning, I., Pijnenburg, Y., et al. (2003). Frontotemporal dementia in The Netherlands: patient characteristics and prevalence estimates from a population-based study. Brain, 126(Pt 9), 2016-2022. doi:10.1093/brain/awg204.

Seelaar, H., Kamphorst, W., Rosso, S. M., Azmani, A., Masdjedi, R., De Koning, I., et al. (2008). Distinct genetic forms of frontotemporal dementia. Neurology, 14, 1220-1226. doi:10.1212/01.wnl.0000319702.37497.72.

Sleegers, K., Kumar-Singh, S., Cruts, M., \& Van Broeckhoven, C. (2008). Molecular pathogenesis of frontotemporal lobar degeneration: basic science seminar in neurology. Archives of Neurology, 6, 700-704. doi:10.1001/archneur.65.6.700.

Snowden, J. S., Neary, D., \& Mann, A. (2002). Frontotemporal dementia. The British Journal of Psychiatry, 180, 140-143. doi:10.1192/bjp.180.2.140.

Tibben, A. (2007). Predictive testing for Huntington's disease. Brain Research Bulletin, 72, 165-171. doi:10.1016/j.brainresbull. 2006.10.023.

Vamos, M., Hambridge, J., Edwards, M., \& Conaghan, J. (2007). The impact of Huntington's disease on family life. Psychosomatics, 48, 400-404. doi:10.1176/appi.psy.48.5.400.

Van der Meer, L., Timman, R., Trijsburg, W., Duisterhof, M., Erdman, R., Van Elderen, T., et al. (2006). Attachment in families with Huntington's disease. A paradigm in clinical genetics. Patient
Education and Counseling, 63, 246-254. doi:10.1016/j. pec.2005.11.019.

Van der Zee, J., Sleegers, K., \& Van Broeckhoven, C. (2008). Invited article: the Alzheimer disease-frontotemporal lobar degeneration spectrum. Neurology, 7, 1191-1197. doi:10.1212/01. wnl.0000327523.52537.86.

van Gael, M. (2002). De missing link tussen trauma en borderline problematiek. Een benadering vanuit de hechtingsproblematiek. Tijdschrift voor Psychotherapie, 28, 365-384.

van Swieten, J., \& Heutink, P. (2008). Mutations in progranulin (GRN) within the spectrum of clinical and pathological phenotypes of frontotemporal dementia. The Lancet Neurology, 7, 965974. doi:10.1016/S1474-4422(08)70194-7.

Van Swieten, J. C. (2007). Genetic basis of frontotemporal dementia. The Lancet Neurology, 6, 840-841. doi:10.1016/S1474-4422(07)70224-7.

Van Swieten, J. C., Rosso, S. M., van Herpen, E., Kamphorst, W., Ravid, R., \& Heutink, P. (2004). Phenotypic variation in frontotemporal dementia and parkinsonism linked to chromosome 17. Dementia and Geriatric Cognitive Disorders, 17, 261264. doi:10.1159/000077150.

White, K. M., Speisman, J. C., \& Kostos, D. (1983). Young adults and their parents: individuation to mutuality. In H. D. Grootevant, \& C. R. Cooper (Eds.),New directions for child development, vol. 22: Adolescent development in the family (pp. 1-4). SanFrancisco: Jossey-Bass. 